\title{
Day-of-the-week effect in some of the Gulf Cooperation Council (GCC) stock markets
}

\author{
A. M. Al-Barrak \\ Finance Department, King Faisal University, Saudi Arabia
}

\begin{abstract}
This paper examines the day-of-the-week effects in some of the Gulf Cooperation Council (GCC) stock markets namely the Saudi Stock Market, the Kuwaiti Stock Exchange, and the Dubai Financial Market. The empirical research was conducted using the variances (ANOVA) test to find if there were significant differences between the daily returns in these markets from January 2002 to December 2005. Results obtained indicate the significant presence of the day of the week effect on the Kuwaiti Stock Exchange (KSE), the highest return is observed on Saturday and the lowest return is observed on Sunday.
\end{abstract}

Keywords: day-of-the-week effect, Gulf cooperation council stock market.

\section{Introduction}

French (1980) originally observed that stock returns are higher than average on the last trading day of the week and lower than average on the first. Since then, a great number of researchers have attempted to explain and examine what has come to be known as the "weekend" or "day-of-the-week" effect. Now, it is well documented in the finance literature that the weekend or the day-of-the-week could affect the performance of the stock market. Most of these researches have documented that the average return on Friday is abnormally high, and the average return on Monday is abnormally low (Agrawal and Tandon [1], and Mills and Coutts [15]). Jaffe and Westerfield [10] and Keim and Stambaugh [12] say that this anomalous empirical finding is one of the most puzzling phenomena in finance.

In this paper, we extend the determination of the day-of-the-week effect existing in a sample of three Gulf Cooperation Council (GCC) stock markets, 
namely the Saudi Stock Market, the Kuwaiti Stock Exchange, and the Dubai Financial Market.

The remainder of the paper is structured as follows. Section 2 is an overview of the GCC stock markets. Section 3 summarises a literature review of the issue and discusses related topics. Section 4 outlines the data used and the methodology that is applied. Section 5 presents the findings and Section 6 is the conclusion.

\section{Overview of the GCC stock markets}

\subsection{The Saudi Stock Market (SSM)}

The Saudi Stock Market (SSM) is relatively young in age compared to the markets in developed countries. Based on Standard and Poor's Emerging Markets Data Base (EMDB), The SSM is classified as an emerging market belonging to the Middle East and North Africa region. An unofficial stock market began in 1934, when the Arabian Automobile Company was created as the first joint stock company in the Kingdom. The number of joint stock companies increased to a total of five by 1954. By 1964, the total had reached 17 , with an issued capital of 29.9 million shares and a value of SR 2,955 million. In May 2007, the number of listed joint stock companies in the Kingdom was 93 in the SSM. Market activities, however, remained largely unregulated until 1985, when the Saudi Arabian Monetary Authority (SAMA) exclusively authorised 12 domestic commercial banks to act as brokers. Electronic trading and settlement systems were implemented in 1988. On 16th June 2003, the Saudi Capital Market Authority (CMA) was established to regulate and develop the Saudi Arabian capital markets and issue the required rules and regulations for the implementation of the provisions of the Capital Market Law aimed at creating an appropriate investment environment. In 2006, the Saudi Government allowed foreigners resident in Saudi Arabia to invest directly in the Kingdom's stock market. Trading days in the SSM were from Saturday to Thursday. However, in June 2006, the CMA reduced the trading days to five, from Saturday to Wednesday.

\subsection{The Kuwait Stock Exchange (KSE)}

The history of Kuwaiti public share holding companies had its origin in the 1950s. The process started with public subscription in 1952 to the shares of the National Bank of Kuwait (NBK) followed in 1954 by the Kuwaiti National Cinema Company (KSC). An Amiri Decree was issued on 14 August 1983 concerning the reorganisation of the Exchange as an independent financial institution. Following the Iraqi invasion of Kuwait in August 1990, trading in the KSE was interrupted for 28 months, which reduced the number of listed companies from 54 to 28. Securities trading became more efficient in 1995 with the implementation of an electronic trading and settlement system. The Kuwaiti Securities Market signed, on December 25 1996, a cross-listing agreement with the Bahrain and Oman Stock Exchanges. Other GCC nationals were granted 
market access in 2000. Non-GCC investors are not allowed to invest directly in the Kuwaiti stock market but may subscribe to overseas based mutual funds trading in Kuwaiti securities. The Waad Future Financial Investment Service, the first equity futures market in the Arab world, was launched in 1996, for a limited number of stocks (Bley and Chen [2]). On July 2006, 172 companies were listed on the KSE. Trading days in KSE are from Saturday to Wednesday.

\subsection{The Dubai Financial Market (DFM)}

Dealing in stocks in the United Arab Emirates (UAE) goes back to the early sixties of the past century, when the government established several joint-stock companies. The Dubai Financial Market was established on 26th March 2000 as a public organisation having independent legal personality. In its early stages, the market played the role of a secondary market for the exchange of stocks issued by joint stock companies, as well as the exchange of bonds issued by the Government of the United Arab Emirates, any of the local government entities, public organisations and institutions within the government, and investment units issued by local investment funds or any other local or foreign financial instrument acceptable to the market. The number of listed securities in the DFM was 30 in July 2006. Trading days in the DFM are from Saturday to Thursday.

Table 1: $\quad$ GCC stock market characteristics (December 2005).

\begin{tabular}{|c|c|c|c|}
\hline Characteristics & SSM & KSE & DFM \\
\hline Stock trading began & 1934 & 1952 & 1989 \\
\hline $\begin{array}{c}\text { Current market system } \\
\text { established }\end{array}$ & 1985 & 1983 & 2000 \\
\hline $\begin{array}{l}\text { Electronic trading } \\
\text { since }\end{array}$ & 1988 & 1995 & 2000 \\
\hline $\begin{array}{c}\text { Number of companies } \\
\text { listed }\end{array}$ & 81 & 173 & 30 \\
\hline $\begin{array}{c}\text { Market capitalization } \\
\text { (US \$ bn) }\end{array}$ & 431 & 115 & 114 \\
\hline $\begin{array}{c}\text { Length of settlement } \\
\text { procedure (days) }\end{array}$ & Real time & 1 & 2 \\
\hline Trading days & $\begin{array}{c}\text { From } \\
\text { Saturday to } \\
\text { Wednesday }\end{array}$ & $\begin{array}{l}\text { From Saturday } \\
\text { to Wednesday }\end{array}$ & $\begin{array}{c}\text { From } \\
\text { Sunday to } \\
\text { Thursday }\end{array}$ \\
\hline
\end{tabular}

\section{Literature review}

As noted above, the presence of the day of the week effect in stock market returns has been widely documented in the finance literature. In the USA market, French [5] observed consistently lower returns for Monday. In fact, the mean returns for Monday were negative for 20 years during 1952-1977. Moreover, Gibbons and Hess [6], Lakonishok and Levi [14], Keim and Stambaugh [12], 
Rogalski [16], Harris [7], and Smirlock and Starts [19] also discovered extensive evidence of the day-of-the-week effect in the USA.

In addition, studies have been conducted on some of the European exchanges. These studies showed that the day-of-the-week effect varied between countries and time periods. Board and Sutcliffe [3] and Hawawini [8] documented in their researches that there was some evidence of the day-of-the-week effect in the London, French, and Finnish Stock Exchanges. In general, it seems to be the case that Mondays and Tuesdays provided lower returns, while the other three days of the week provided higher returns. Condoyanni et al [4] found that returns inform the Greek Stock Exchange were negative on Tuesdays and Wednesdays. In addition, the findings of Savva et al [18] indicate that the day-of-the-week effect is present in either intercept or autocorrelation terms (or both) in the mean equation for the UK, France, Italy, Spain, and Swiss stock markets, but not from Germany and the USA. However, Santesneses [17] did not find a day-of-theweek effect in the Spanish Stock Exchange, nor did Jennergren and Sorensen [11] for the Danish markets.

Regarding the Asian stock exchanges, Kim et al [13] analysed the day-of-theweek effects in the Thailand and Korea stock markets for the period January 1980 - December 1988. The findings of the study did not follow the pattern of high or positive returns on the last trading day and low or negative returns at the start of the trading week. Also, testing for the weekend-effect did not produce any evidence. Wong et al [20] extended study of the day-of the week effect to the stock markets of Hong Kong, Taiwan, Thailand, Singapore, and Malaysia for the period from January 1975 to May 1988. It was found that the day-of-the week effect is present in all markets except Taiwan. Lastly, Hui [9] investigated the day to day behaviour of stock market returns for the USA, Japan, Hong Kong, South Korea, Singapore, and Taiwan. The result showed that Hong Kong, Taiwan and Singapore follow the general pattern of higher average stock returns on the last trading day of the week and lower than average returns on the first, but the mature markets of the USA and Japan and the relatively new Korean stock market do not confirm to the same pattern.

\section{Data and methodology}

There are seven GCC stock markets, namely the Bahrain, Abu Dhabi, Dubai, Kuwait, Oman, Qatar, and Saudi Arabia stock markets. However, this study covers only three of them: SMM, KSE, and DFM. The reason for selecting these three stock markets is that they are the largest stock markets in term of market capital, volume traded, and shares traded. The data for selected stock markets were obtained from their official websites.

The daily return of each stock index is computed as follows:

$$
R_{t}=\left(P_{t}-P_{t-1}\right) / P_{t-1}
$$

Where $R_{t}$ daily return, $P_{t}$ and $P_{t-1}$ are the closing prices of the index are period $t$ and $t-1$, respectively.

To examine the day-of-the week effect of the three different stock indices, an analysis of variances (ANOVA) test was used to find if there were significant 
differences between the independent variables. A parametric test, 1-way ANOVA, was employed because the data conforms to an ordinal scale and because of the sample size. The test was used with a significant level of 5\%, so the null hypothesis is rejected if the result of the test is less than $5 \%$. The hypotheses in this study are as follows:

$\mathrm{H}_{0}=$ No difference exists in the returns across the days of the week.

$\mathrm{H}_{1}=\mathrm{A}$ difference exists in the returns across the days of the week.

\section{Empirical results}

The objective of this empirical test was to determine whether the three GCC stock markets tend to exhibit a day-of-the-week effect. Firstly, descriptive statistics were compiled by day of the week for each stock market, shown in Table 2. Table 2 illustrates the mean return and standard deviation for every day of the week for the three GCC stock markets. From Table 2, the lowest return happened on Sunday for the SSM (-0.0003) and KSE (0.0002), and on Wednesday for DFM (-0.0001). Interestingly, KSE recorded positive returns for all days of the week, unlike SSM and DFM. Regarding the volatility, measured by the standard deviations, the most volatile day in SSM was Saturday (0.0152), as it was also for KSE (0.0094). For DFM, Tuesday (0.0500) was the most volatile.

Table 2: $\quad$ Means, and standard deviations (SD), of GCC stock markets.

\begin{tabular}{|c|c|c|c|c|c|c|}
\hline \multirow{2}{*}{ Days } & \multicolumn{2}{|c|}{ SSM } & \multicolumn{2}{c|}{ KSE } & \multicolumn{2}{c|}{ DFM } \\
\cline { 2 - 7 } & Mean & SD & Mean & SD & Mean & SD \\
\hline Saturday & 0.0018 & 0.0152 & 0.0032 & 0.0094 & 0.0030 & 0.0139 \\
\hline Sunday & -0.0003 & 0.0099 & 0.0002 & 0.0081 & 0.0015 & 0.0136 \\
\hline Monday & 0.0013 & 0.0116 & 0.0022 & 0.0081 & 0.0022 & 0.0183 \\
\hline Tuesday & 0.0019 & 0.0122 & 0.0014 & 0.0082 & 0.0042 & 0.0500 \\
\hline Wednesday & 0.0026 & 0.0126 & 0.0024 & 0.0072 & -0.0001 & 0.0316 \\
\hline Thursday & 0.0028 & 0.0079 & ------ & ------ & 0.0033 & 0.0120 \\
\hline
\end{tabular}

Table 3 demonstrates the result of the 1-way ANOVA test of day-of-the-week effects on returns differences in GCC stock markets, using SPSS. The values of the F-test and P-value are insignificant at the 5\% level for all the markets except KSE (0.004 p-value). Comparing the mean returns of KSE (Table 2), Saturday has a mean score of 0.0032 , Sunday a mean score of 0.0002 , Monday a mean score of 0.0022 , Tuesday a mean score of 0.0014 , and Wednesday a mean score of 0.0024 .

To make further investigation into the mean differences in KSE, the LSD Multiple Comparisons test was implemented. Comparing the mean returns of KSE by using LSD Multiple Comparisons at the 0.05 level, as shown in Table 4, Saturday is significantly different from Sunday and Tuesday; Sunday is significantly different from all days except Tuesday; Monday and Wednesday are significantly different from Sunday; Tuesday is significantly different from Saturday. 
Table 3: One-way ANOVA result of day-of-the-week effects on returns differences in GCC stock markets.

\begin{tabular}{|c|c|c|c|}
\hline Stock markets & F-test & P-value & Null hypothesis \\
\hline SSM & 1.789 & 0.112 & Do not reject \\
\hline KSE & 3.885 & $\mathbf{0 . 0 0 4}$ & Reject \\
\hline DFM & 0.636 & 0.672 & Do not reject \\
\hline
\end{tabular}

Bold and underlined figures refer to a 5\% significant difference.

Table 4: $\quad$ LSD Multiple Comparisons results.

\begin{tabular}{|c|c|c|c|}
\hline (I) D_KSM & (J) D_KSM & Mean Difference (I-J) & Sig. \\
\hline \multirow[t]{4}{*}{ Saturday } & Sunday & 0.0029783 & 0.000 \\
\hline & Monday & 0.0010374 & 0.202 \\
\hline & Tuesday & 0.0018015 & $\underline{0.027}$ \\
\hline & Wednesday & 0.0007631 & 0.348 \\
\hline \multirow[t]{4}{*}{ Sunday } & Saturday & -0.0029783 & $\underline{0.000}$ \\
\hline & Monday & -0.0019409 & 0.017 \\
\hline & Tuesday & -0.0011768 & 0.148 \\
\hline & Wednesday & -0.0022151 & $\underline{0.006}$ \\
\hline \multirow[t]{4}{*}{ Monday } & Saturday & -0.0010374 & 0.202 \\
\hline & Sunday & 0.0019409 & $\underline{0.017}$ \\
\hline & Tuesday & 0.0007641 & 0.348 \\
\hline & Wednesday & -0.0002743 & 0.736 \\
\hline \multirow[t]{4}{*}{ Tuesday } & Saturday & -0.0018015 & $\mathbf{0 . 0 2 7}$ \\
\hline & Sunday & 0.0011768 & 0.148 \\
\hline & Monday & -0.0007641 & 0.348 \\
\hline & Wednesday & -0.0010383 & 0.202 \\
\hline \multirow[t]{4}{*}{ Wednesday } & Saturday & -0.0007631 & 0.348 \\
\hline & Sunday & 0.0022151 & $\underline{0.006}$ \\
\hline & Monday & 0.0002743 & 0.736 \\
\hline & Tuesday & 0.0010383 & 0.202 \\
\hline
\end{tabular}

Bold and underlined figures refer to a 5\% significant difference.

\section{Conclusion}

This paper provides a study of the day-of-the-week-effect in three Gulf Cooperation Council emerging stock markets using the one-way ANOVA test. The day-of-the-week effect on both the mean and standard deviation (volatility) 
of stock returns are studied in this paper. Daily stock returns during January 2002 to December 2005 from Saudi Arabia, Kuwait, and Dubai were applied in the empirical work. The results obtained indicate a significant presence of the day-of-the-week effect in the Kuwait Stock Exchange only. This confirms the notion that the day-of-the-week effect is not just features of the stock markets of the United States and other developed countries but of emerging markets.

\section{References}

[1] Agrawal, A. and Tandon, K. Anomalies or illusions? Evidence from stock markets in eighteen countries, Journal of International Money and Finance, 13, pp. 83-106, 1994

[2] Bley, J. and Kim Heng Chen, Gulf Cooperation Council (GCC) stock markets: the dawn of a new era, Globe Finance Journal, Forthcoming, 2006

[3] Board, J. L. C. and Sutcliffe, C. M. S., The Weekend Effect in UK stock market returns. Journal of Business Finance and Accounting, 15, pp. 119213, 1998

[4] Condoyanni, L., O'Hanlon, J., and Ward C. W. R., An investigation of daily seasonality in the Greek equity market, in: Guimaraes, R., Kingsman, B., and Taylor, S., editors. Reappraisal of the efficiency of financial markets. NATO ASI Series, vol. F54. Berlin: pp. 229-57, 1989

[5] French, K. R., Stock returns and the week-end effect, Journal of Financial Economics, 8, pp. 56-59, 1980

[6] Gibbons, M. and Hess, P., Day of the week effect and asset returns, Journal of Business, 54, pp. 579-596, 1981

[7] Harris, L., An examination of the robustness of the week-end effect, Journal of Financial and Quantitative Analysis, 24, pp. 133-156, 1986

[8] Hawawini, G., Market efficiency and equity pricing: international evidence and implications for global investing. University of Pennsylvania. Working Paper, 1998

[9] Hui, Tak-Kee, Day-of-the-week effects in US and Asia-Pacific stock markets during the Asian financial crisis: a non-parametric approach. Omega, 33, 277-282, 2005

[10] Jaffe, J. and Westerfield, R., The week-end effect in common stock returns: the international evidence, Journal of Finance, 40, pp. 237-44, 1985

[11] Jennergren, P. and Sorensen, B., Random walks and anomalies on the Copenhagen Stock Exchange in the 1890s, in: Guimaraes, R., Kingsman, B., and Taylor, S., editors. Reappraisal of the efficiency of financial markets. NATO ASI Series Vol. FS4, Berlin: pp. 261-282, 1989

[12] Keim, D. and Stambaugh, R., A further investigation of the weekend effect in stock returns, Journal of Finance, 39, pp. 819-35, 1984

[13] Kim, D. J. et al., A comparative analysis of anomalies and daily returns in emerging Asian stock markets. Western Decision Science Institute, Working Paper, 1998

[14] Lakonishok, J. and Levi, M., Weekend effects on stock returns, a note, Journal of Finance, 37, pp. 883-889, 1982 
[15] Mills, T. and Coutts, J., Calendar effect in the London Stock Exchange FTSE indices, European Journal of Finance, 1, pp. 79-93, 1995

[16] Rogalski, R., New findings regarding day of the week returns over trading and non-trading periods. Journal of Finance, 39, pp. 1603-1614, 1984

[17] Santesneses, M., An investigation of the Spanish stock market seasonalities. Journal of Business Finance and Accounting, 13, pp. 267276, 1986

[18] Savva, C., Osborn, D. R. and Gill, L., The day of the week effect: evidence from six European stock markets and the US. University of Manchester. Working paper, 2006

[19] Smirlock, M. and Starts, L., Day-of-the-week and intraday effects in stock returns, Journal of Financial Economics, 17, pp. 197-210, 1986

[20] Wong, K. A., Hui, T. K., and Chan, C. Y., Day-of-the-week effects: evidence from developing stock markets. Applied Financial Economics, 2, pp. 49-56, 1992 